\section{IMF Working Paper}

(C) 1998 International Monetary Fund
This is a Working Paper and the author(s) would welcome any comments on the present text. Citations should refer to a Working Paper of the International Monetary Fund. The views expressed are those of the author(s) and do not necessarily represent those of the Fund.

$\mathrm{WP} / 98 / 9$

INTERNATIONAL MONETARY FUND

Research Department

\title{
Uncertainty, Flexible Exchange Rates, and Agglomeration*
}

Prepared by Luca Antonio Ricci

Authorized for distribution by Peter Isard

February 1998

\begin{abstract}
This paper shows that exchange rate variability promotes agglomeration of economic activity. Under flexible rates, firms located in large markets have lower variability of sales, reinforcing concentration of firms there. Empirical evidence on OECD countries demonstrates (1) that the negative effect of country size on variability of industrial production is stronger after the 1973 collapse of fixed rates and (2) for small (large) countries, exchange rates variability has a longrun negative (positive) effect on net inward FDI flows. Two implications arise: creating a currency area fosters agglomeration in the area, and a two-stage EMU may exacerbate the current uneven regional development.
\end{abstract}

JEL Classification Numbers: F12; F31; F33; F4; L16; R12

Keywords: Flexible exchange rates, Agglomeration, Two-stage EMU

Author's E-Mail Address: 1ricci@imf.org

"I am particularly indebted to Eswar Prasad, but would also like to thank Peter Christoffesen, Giovanni dell'Ariccia, Ilan Goldfajn, Hamid Faruqee, Lorenzo Giorgianni, and participants in the Fifth meeting (Graduate Institute of International Studies, Geneva, June '97) of the European Science Fundation-funded Research Group on "European Economic Integration" for helpful discussion. I am grateful to Jeffery Gable, Susana Mursula, and Mirko Novakovic for patient help with data collection. The ideas presented in the paper reflect those of the author and not necessarily those of the IMF. 


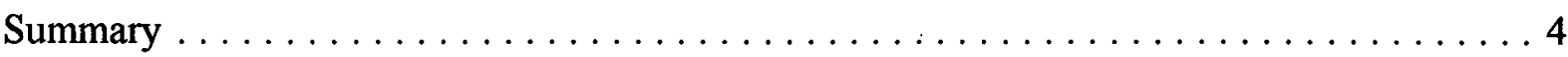

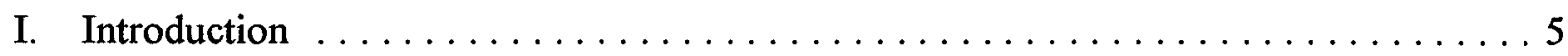

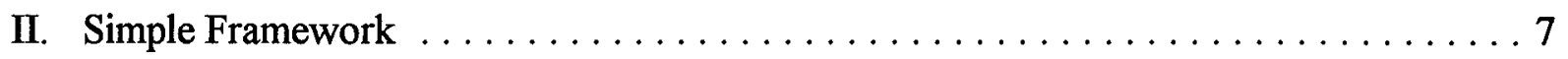

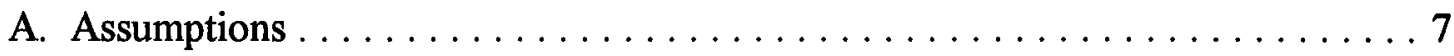

Uncertainty, Timing, and Pricing ................ 8

Before the Resolution of Uncertainty $\ldots \ldots \ldots \ldots \ldots \ldots \ldots$

After the Resolution of Uncertainty . . . . . . . . . . . . . 9

Preferences and Wealth .......................... 9

Market Structure and Technology $\ldots \ldots \ldots \ldots \ldots \ldots \ldots \ldots$

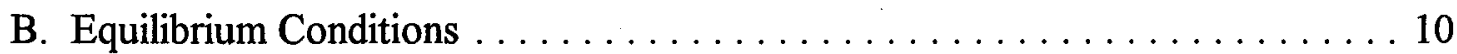

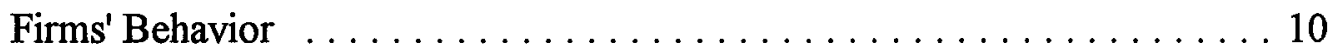

Consumers' Behavior ......................... 11

Equilibrium in the Goods and Money Market .............. 12

C. Equilibrium in the Absence of Uncertainty $\ldots \ldots \ldots \ldots \ldots \ldots \ldots \ldots, \ldots \ldots \ldots$

III. Uncertainty for Given Location Structure $\ldots \ldots \ldots \ldots \ldots \ldots \ldots \ldots \ldots \ldots$

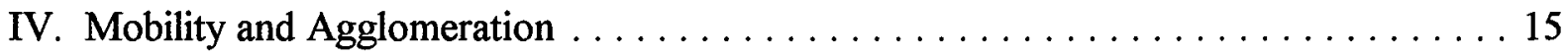

A. Case 1: Mobility of Firms, No Labor Mobility $\ldots \ldots \ldots \ldots \ldots \ldots \ldots \ldots$

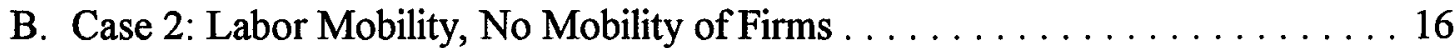

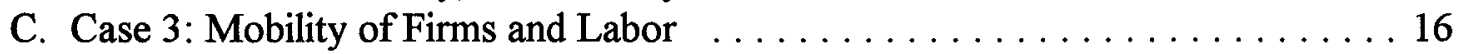

D. Dispersion Forces . . . . . . . . . . . . . . . . . . . . . 16

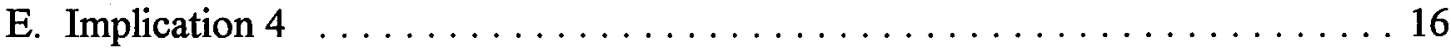

V. Empirical Evidence ............................... 17

A. Variability of Industrial Production and Exchange Rate Regime . . . . . . . 17

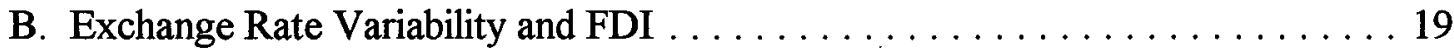

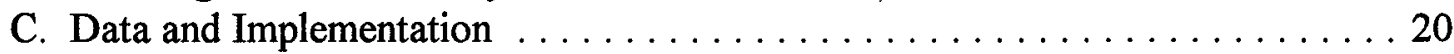

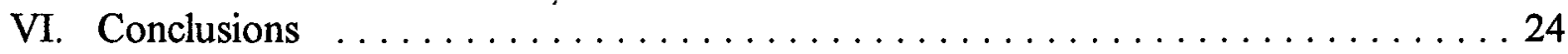


Text Tables

1. Variability of Industrial Production Before and After the Collapse of Bretton Woods . 19

2. FDI and Exchange Rate Variability: Small Country Panel, 1975-93 . . . . . . . . 22

3. FDI and Exchange Rate Variability: Large Country Panel, 1975-93 . . . . . . . . . . 23

\section{Figures}

1. FDI -Net Inward FDI Flow as a Share of GDP (Endogenous Variable) . . . . . . 26

2. RLC1-One Year Growth Rate of the Real Labor Cost . . . . . . . . . . . . 27

3. RLC2-One Year Growth Rate of the Real Labor Cost . . . . . . . . . . . . . . . 28

4. E1-One Year Standard Deviation of the Monthly Growth Rate of the Nominal Effective Exchange Rate . . . . . . . . . . . . . . . . . . . . . . . . 29

5. E3-Three Years Standard Deviation of the Monthly Growth Rate of the Nominal Effective Exchange Rate . . . . . . . . . . . . . . . . . . . . . . . 30

Appendix Table

1a. STD of Industrial Production Growth Rate and Country Size

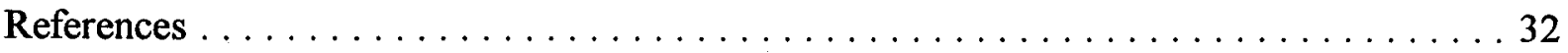




\section{SUMMARY}

This paper shows that exchange rate variability can promote agglomeration of economic activity. Under flexible exchange rates, firms located in large markets tend to have lower variability of sales and higher expected profits, which induces a self-reinforcing concentration of firms in large markets. This outcome is independent of the usual forward and backward linkages formally developed in the economic geography literature.

Empirical evidence on OECD countries is consistent with the prediction of the model. First, the negative effect of country size on the variability of industrial production (variability is higher for small countries) has been stronger since the collapse of the Bretton Woods fixed rate system in 1973. Second, for small countries, variability of exchange rates has a long-run negative effect on net inward FDI flows, while for large countries the effect is positive.

One important implication is that the creation of a currency area imposes a negative externality on firms outside the area and fosters agglomeration in the currency area. Given the peripherality of countries that may not participate immediately in the EMU, a two-stage EMU may exacerbate the current uneven regional development. 


\section{INTRODUCTION}

This paper offers a theoretical explanation for a positive effect of exchange rate variability on agglomeration of economic activity. It shows that exchange rate variability induces greater variability of sales for firms located in small markets than for those located in large markets, generating an incentive for firms to locate in large markets. Empirical evidence from OECD countries supports the prediction of the model presented in this paper. First, flexible exchange rates widen the gap between the variability of industrial output in small and large countries. Second, for small countries, variability of exchange rates has a negative longrun effect on the flow of net inward foreign direct investment (FDI), while for large countries this effect is positive, suggesting that such variability fosters agglomeration.

One important implication of the agglomeration incentives generated by exchange rate variability is that the creation of a currency area imposes a negative externality on firms outside the area, and promotes agglomeration in the currency area. Given the peripherality of countries that may not participate immediately in the European Monetary Union (EMU), twostage $\mathrm{EMU}^{2}$ may exacerbate the current uneven level of regional development.

There is a growing interest in understanding whether exchange rate regimes have an effect on location choices of firms and the production structure of countries. The upsurge of the new-Keynesian economic literature in the last two decades has provided a variety of theoretical justifications for short-run price rigidities and the effect of monetary variables on real variables (see, for example, Mankiw and Romer, 1992). At the same time, the prospect of a monetary union and the sensitivity of the European Union (EU) to location issues (particularly due to the low labor mobility within the EU and the importance of regional convergence for the success of the European Single Market) has spurred interest in understanding the possible interactions between exchange rate regimes, and countries' production and trade structures, both inside and outside the EU (EC, 1990; Eichengreen, 1990; Fatas 1996; Frankel and Rose, 1996; Krugman, 1990, 1993; Ricci, 1997a, 1997b).

Extensive empirical evidence has illustrated that real and nominal exchange rate movements are strictly and positively correlated in the short and medium run, as prices do not offset changes in the nominal exchange rate quickly enough. This stylized fact suggests the possibility of extensive links between monetary and real variables in international environments, indicating unexploited synergies between trade and location theory on the one hand and new Keynesian macroeconomic theory on the other hand. This is particularly true for 'new' trade and location theory, which shares the fundamental assumptions of imperfect competition with some modern approaches to the micro foundation of price rigidities.

\footnotetext{
${ }^{2}$ This term is used to define a situation where some countries would participate immediately in EMU and other countries would join later.
} 
The literature on location and economic geography usually neglects the effect of monetary and exchange rate variables on the location choices, ${ }^{3}$ while the literature on exchange rate variability and $\mathrm{FDI}^{4}$ is mostly based on partial equilibrium analysis, which is inadequate for investigating the location and agglomeration consequences of exchange rate variability.

Luehrman (1990) discusses the foreign currency exposure of U.S. firms arising from, among other things, demand shifts induced by exchange rate changes. He mentions that U.S. firms should suffer much less than foreign competitors from the variability of the exchange rate, because of the relatively large size of the U.S. market. The present work provides a theoretical and empirical foundation to support this view.

Ricci (1997a) presents a two-country, two-sector model that investigates the implications of different exchange rate regimes on the location choices of firms and on the pattern of specialization of countries when real and monetary shocks occur in the presence of short-run rigidities. The results show that countries become more specialized under flexible rates than under fixed rates: the endogenous exchange rate movements offer a form of adjustment to firms belonging to the net export sector of each country, and constitutes a form of disturbance to firms belonging to the net import sector. As the paper focuses on the specialization of countries and the adjustment role of exchange rates, countries are kept symmetric to simplify the exposition of the mechanism. In this way, however, agglomeration effects are neutralized.

The focus of this paper is on agglomeration of economic activity and the variability of exchange rates. Hence, it adopts a similar approach in formalizing a monetary model of trade with market rigidities, but allows for different sizes of countries. Instead of focusing on the adjustment role of the exchange rate (as analyzed for demand, supply and monetary shocks in the earlier Ricci 1997a paper) this paper focuses on the component of exchange rate variability that is not directly imputable to the short-run adjustment: for example, the volatility due to the response of financial markets to expectations of future policies, to political

\footnotetext{
${ }^{3}$ Since Krugman (1991) emphasized the agglomeration effects deriving from trade costs and partial factor mobility in the usual new trade theory setup (monopolistic competition, increasing returns to scale and product differentiation) numerous other contributions have investigated related aspects: intermediate inputs (Krugman and Venables, 1996; Venables, 1996), congestion (from land rent, as in Elizondo and Krugman, 1992; from fixed local supply of housing, as in Helpman, 1996); trade policy (Elizondo and Krugman, 1992); taxation and spending (Trionfetti, 1997); debt policy (Trionfetti 1996); growth (Martin and Ottaviano, 1996); and different infrastructures across locations (Martin and Rogers, 1995).
}

${ }^{4}$ See for example, Goldberg and Koldstad (1994), Cushman (1988), Broll and Zilcha (1992), and Broll, Wahl, and Zilcha (1995). 
statements, or to 'Soros's signals. In this model, the exchange rate is an exogenous random variable.

The main intuition is that under flexible exchange rates, firms located in large markets tend to have a lower variability of sales, which induces a self-reinforcing concentration of firms in large markets whenever firms dislike such variability. ${ }^{5}$ This outcome is independent of the usual forward and backward linkages formally developed in the economic geography literature. A simple example may clarify the intuition. Assume a sudden depreciation of the Spanish peseta versus the German mark. As prices will not respond quickly enough there will be a relative price movement across the two countries, inducing a shift in expenditures from German varieties of, say, cars to Spanish varieties. Such expenditure shift is of a given absolute size for both countries, but will affect unequally the producers of the country hosting the smallest share of the industry. Therefore under flexible exchange rates, producers in such location will face a larger variability of sales than their competitors in other countries.

The paper is organized as follows. Section II proposes a simple framework for the analysis described above. Section III derives the location incentives for a given location structure. Section IV investigates the agglomeration effects when one allows for factor and firms mobility. Section V describes the empirical evidence, while Section VI draws conclusions.

\section{A SIMPLE FRAMEWORK}

\section{A. Assumptions}

The modeling strategy hinges on two main rationales. First, in order to isolate the agglomeration effects of the exchange rate, the usual forward and backward linkages, extensively analyzed in the economic geography literature, are neutralized by assuming the absence of costs and impediments to trade. Second, in order to describe the intuition in a tractable way, the framework is kept simple. The implications of extending the model are then discussed; however, such extensions were found to offer no additional insights (they would instead prevent the derivation of closed-form solutions and would impose a presentation of the results on the basis of simulations).

${ }^{5}$ There are several reasons why firms dislike variability of sales or why such variability affects expected profits negatively. Decreasing returns to scale in the presence of price rigidities generate a profit function which is concave in output (as in Ricci, 1997a). Costs of firing workers, of entering into a bankruptcy process, or of maintaining a stock, induce firms to dislike variability of sales. Other reasons are given by risk-averse owners facing incomplete financial markets, or risk-averse managers facing imperfect labor markets or enjoying nonmarketable payoffs (such as reputation, satisfaction). 
Similar to the Ricci (1997a) model, this model combines aspects of the new-Keynesian literature on market rigidities with new trade theory. Assume a simple new trade theory world (Helpman and Krugman, 1985) with many countries (N) and many firms $(\mathbf{n}>\mathbf{N})$ producing different products, which enter symmetrically into a Dixit-Stiglitz utility function. As in Blanchard and Kyotaki (1987), money is introduced in the utility function and price rigidities arise from menu costs. Country $k$ is inhabited by $\mathbf{L}_{k}$ individuals $(k=1, \ldots N)$. Labor is homogenous and is the only factor of productions. Both international labor immobility and mobility are discussed. Goods are freely tradable and there are no trade costs. ${ }^{6}$

\section{Uncertainty, Timing, and Pricing}

Uncertainty arises from exogenous shocks to the exchange rates. The model allows for temporary trade imbalances, financed by money flows. ${ }^{7}$

\section{Before the Resolution of Uncertainty}

Firms choose where to locate and pay a fixed cost. Then, the wage (w) is set at the level that would provide the local natural rate of employment in the absence of shocks. ${ }^{8}$ Hence, $w$ is equal across locations (separate wage bargaining across location may imply different wages across location if wage-setters care about variability of employment, as will be discussed later). Then, each firm sets its optimal price as markup over expected marginal cost (firms neglect the possible impact of their price setting on the variability of the sales).

\footnotetext{
${ }^{6}$ In order to neutralize the usual agglomeration effects stressed by the economic geography literature and to focus on those arising from exchange rate variability and market size in the presence of price rigidities, trade costs are not introduced.
}

${ }^{7}$ As the aim is to focus on the real consequences of exchange rate variability, the framework is kept simple at the expense of a proper formalization of the financial sector of the economy. Ideally, exchange rate movements would be caused by shocks originating in financial markets. A decrease in demand for financial assets of one country (for example, due to expected policy changes) would cause a depreciation of the currency of that country: the capital outflow would then be associated with a trade surplus. One can think of the model's features as a reduced form of this more extensive setup.

${ }^{8}$ Equivalently one could assume that $w$ is set so as to equalize the approximate expected real wage across locations. The price indexes are identical across locations (no trade costs) apart from the exchange rate components, which are random and enter nonlinearly. By approximating the expectation of a nonlinear function as the nonlinear function of the expected values, the approximate expected price indexes are identical across locations. Hence, the nominal wage will be identical across locations. 


\section{After the Resolution of Uncertainty}

Menu costs prevent price adjustments. A new equilibrium in the money and goods market is reached. Workers supply as much labor as demanded by firms, while firms sell as much as demanded by consumers. Hence, fluctuations in employment and output are demand driven. Labor is normalized so that in full employment (in the absence of shocks) every worker supplies one unit of labor.

\section{Preferences and Wealth}

All individuals share the same utility function. A representative consumer ${ }^{9}$ of country $\mathbf{j}$ chooses nominal money balances $\left(\mathbf{m}_{j}^{\prime}\right)$ and consumption of product varieties ${ }^{10}\left(\mathbf{c}_{\mathrm{ij}}\right)$ so as to maximize the following preferences:

$$
\left(\sum_{i=1}^{n} c_{i j}^{\frac{\sigma-1}{\sigma}}\right)^{\frac{\lambda \sigma}{\sigma-1}}\left(m^{\prime}{ }_{j} / P_{j}\right)^{1-\lambda}, \quad 0<\lambda<1 \quad \sigma>1
$$

where $P \mathbf{j}$ is the true price index of consumption in country $\mathbf{j}$, and $\boldsymbol{\sigma}$ is the elasticity of substitution among varieties of the same good.

The nominal wealth of a representative individual of country $j\left(j_{k}\right)$ is the sum of his income $\left(\mathbf{y}_{\mathrm{j}}\right)$ and of his endowment of domestic currency $\left(\mathbf{m}_{\mathrm{j}}\right)$. His endowment of money is a fraction $1 / \mathrm{L}$ of the domestic stock of money. Each individual supplies labor to domestic firms at the given wage and receives profits from these firms; his income is therefore a share $1 / \mathrm{L}$ of domestic firms' revenues. Money is the only asset. ${ }^{11}$ The consumer' $s$ budget constraint is:

$$
\sum_{i=1}^{n} p_{i}^{j} c_{i j}+m_{j}^{\prime}=q_{j} \equiv m_{j}+y_{j}
$$

where $\mathbf{p}_{\mathbf{i}}$ is $_{\text {in }}$ the price of variety i measured in the currency of the consumer's country, $j$.

${ }^{9}$ Agents in different countries need to be distinguished, as they may face different prices.

${ }^{10}$ Henceforth simply 'varieties.'

${ }^{11}$ Money in the utility function in a one-period model is conceptually an asset and technically a good. 


\section{Market Structure and Technology}

The market structure is similar to the usual large group monopolistic competition based on Dixit-Stiglitz (1977) and often adopted in trade theory thereafter (see, for example, Helpman and Krugman, 1985). The main departure from this setup is the introduction of price rigidities: firms choose optimal prices before the resolution of uncertainty; after the realization of the shocks, menu costs prevent the firms from adjusting their prices, and firms choose optimal employment and output.

Production functions are identical for all firms and of the usual type in new trade theory. As all firms in the same location will always face the same situation, the behavior of the representative firm for each location is analyzed. The total employment of the representative firm in location $k\left(l_{k}\right)$ is the sum of the fixed number of workers the firm has hired before the resolution of uncertainty plus the number of workers necessary to carry out the optimal production $\left(\mathbf{x}_{\mathbf{k}}\right)$ chosen after the resolution of uncertainty:

$$
l_{k}=\alpha+\beta x_{k}
$$

\section{B. Equilibrium Conditions}

\section{Firms' Behavior}

Once firms have chosen to enter a market, before the resolution of uncertainty, a typical firm of country $k$ takes the wage and other firms' behavior as given and chooses its price ( $\mathbf{p}_{\mathbf{k}}$ in local currency) so as to maximize expected profits $\left(\pi_{k}\right)$ :

$$
E\left[\pi_{k}\right]=E\left[p_{k} x_{k}^{d}-w l_{k}\right]-\operatorname{Var}\left[x_{k}\right] \quad \forall k=1, \ldots, n
$$

where $\mathbf{E}$ is the expectation operator, and $\mathbf{x}_{\mathbf{k}}{ }_{\mathrm{i}}$ is the world demand for the representative variety produced in country $\mathrm{k}$ :

$$
x_{k}^{d}=\sum_{j=1}^{N} C_{k j} \quad \forall j=1, \ldots N \wedge \forall k=1, \ldots N
$$

Firms are assumed to care about variability of sales ( $\left.\operatorname{Var}\left[\mathbf{x}_{\mathbf{k}}\right]\right)$. In the introduction, a number of reasons for this behavior are described. Here, the variability of sales is simply introduced in the profit function in an ad hoc fashion and firms do not consider the impact of their pricing 
strategy on the variability of sales. ${ }^{12}$ The implications of endogenizing firms' dislike for variability of sales will be discussed later.

The optimal price $\left(\mathbf{p}_{\mathrm{k}}\right)$ is therefore set as a markup over the expected marginal cost:

$$
p_{k}=\frac{\sigma}{\sigma-1} w \beta=1 \quad \forall k
$$

where $\boldsymbol{\sigma}$ approximates, for $\mathbf{n}$ large enough, the perceived elasticity of demand. For notational convenience, units of the labor input requirement are chosen so as to normalize the price to 1 . After the resolution of uncertainty, firms choose optimal employment.

\section{Consumers' Behavior}

After the resolution of uncertainty, consumers choose optimal demand for money and for consumption of each product variety. As all individuals of one country face the same prices and have the same homothetical utility function, one can easily derive the aggregate demands of country $\mathrm{j}$ for money $\left(\mathbf{M}_{\mathrm{j}}\right)$ and for each variety produced in country $\mathrm{k}\left(\mathbf{C}_{\mathrm{k} j}\right.$, $\mathrm{j}=1, \ldots \mathrm{N})$ :

$$
C_{k j}=\frac{\left(p_{k} e j k\right)^{-\sigma}}{P_{j}^{1-\sigma}} \lambda Q_{j} \quad M_{j}^{\prime}=(1-\lambda) Q_{j} \quad \forall k_{2}
$$

with

$$
\begin{aligned}
& P_{j}=\left(\sum_{k=1}^{N} n_{k}\left(p_{k} e_{j k}\right)^{1-\sigma}\right)^{\frac{1}{1-\sigma}}=P_{f} e_{i f} \\
& Q_{j}=\sum_{i_{j}=1}^{n_{j}} n_{i_{j}} p_{i_{j}} x_{i_{j}}+M_{j}=L q_{j} \quad \forall j=1, \ldots n
\end{aligned}
$$

where $\mathbf{e}_{\mathbf{j k}}$ is the bilateral exchange rate defined as units of currency $j$ for one unit of currency $k, \mathbf{P}_{\mathbf{k}}$ is the true price index of country $k$, and $\mathbf{n}_{\mathbf{k}}$ is the number of varieties produced in country

${ }^{12}$ For the purposes of the paper, this setup is equivalent to assuming that risk-averse agents care about the expected utility from profits. 
$k, Q_{j}$ is the aggregate wealth of country $j$, and the subscript $i_{j}$ is an index of the variety produced in location $\mathrm{j}$.

Consumers of different countries demand the same variety in different amounts because the exchange rate realizations affect the relative prices.

\section{Equilibrium in the Goods and Money Market}

Equilibrium in the goods and money markets requires:

$$
x_{k}=x_{k}^{d} \quad M_{k}=M^{\prime}{ }_{k} \quad \forall k
$$

The balance of payment is always in equilibrium, as trade imbalances are offset by opposite money flows (see footnote 6).

\section{Equilibrium in the Absence of Uncertainty}

In the absence of shocks, all bilateral exchange rates are equal to 1 . All firms employ the same amount of labor, produce the same output, and charge the same price. As prices are equal, an identical share of expenditure will be allocated to each variety. Every consumer will consume all varieties in the same amount. Full employment is ensured by the wage level. The only difference across countries is given by their size (endowment), which is proportionally reflected in the number of varieties produced locally, in aggregate income, and in aggregate wealth.

From the Sections II.A. and II.B., one derives the following results, after normalizing the exchange rate and the price of each variety to 1 :

$$
\begin{aligned}
& p_{k}=e=1 \\
& x_{k}=l_{k}=\alpha \sigma=\frac{\lambda Q}{n}=\frac{\lambda}{1-\lambda} \frac{M}{n}, \quad n_{k}=\frac{L_{k}}{\alpha \sigma} \\
& Q_{k}=n_{k} \alpha \sigma+M_{k}, \quad M_{k}=\frac{1-\lambda}{\lambda} n_{k} \alpha \sigma, \quad P_{k}=n^{\frac{1}{1-\sigma}}
\end{aligned}
$$


where $\mathbf{M}, \mathbf{Q}$, and $\mathbf{n}$ are the equilibrium world real stock of money, real wealth, and number of varieties.

As one can see, in the absence of shocks, any initial allocation of resources is an equilibrium, as the absence of trade costs inhibits the usual agglomeration effects stressed by the economic geography literature.

\section{UNCERTAINTY FOR GIVEN LOCATION STRUCTURE}

This section takes the country size and firms' location choices as given and investigates the effect of exchange rate variability, in the presence of price rigidities, on the variability of sales of firms located in different regions. Hence, it analyzes firms' location incentives and speculates on the long-run implications for location equilibria, both in the presence and in the absence of factor mobility.

Let exchange rate shocks occur, once wages and prices are set. A simple comparative statics exercise will allow to analyze the implied changes in demand faced by firms at each location. Then, one can compute the variability of sales that these firms expect, and investigate the dependence of such variability on the world market share of each location.

After normalizing prices to one, substituting for the price index, and imposing the money market equilibrium, the equation for sales can be rewritten in the following way:

$$
p_{k} x_{k}=x_{k}=\frac{\lambda}{1-\lambda} \frac{\sum_{j=1}^{N} e_{k j} M_{j}}{\sum_{j=1}^{N} n_{j} e_{k j}^{1-\sigma}}
$$

Hence, the percentage change in sales of the representative firm located in $k\left(\chi_{k}\right)$ is given by:

$$
\chi_{k}=\sigma \sum_{j=1}^{N} \eta_{j} \varepsilon_{k j}
$$

where $\chi_{\mathrm{k}}=\mathrm{dx}_{\mathrm{k}} / \mathrm{x}_{\mathrm{k}}, \eta_{\mathrm{k}}=\mathrm{n}_{\mathrm{k}} / \mathrm{n}$, and $\varepsilon_{\mathrm{kj}}=\mathrm{de}_{\mathrm{kj}} / \mathrm{e}_{\mathrm{kj}}$.

Hence, variability of sales of firms located in country $k$ is small if: country $k$ is large $\left(\eta_{j}\right.$ small), the variances of the bilateral exchange rates of country $k\left(\operatorname{Var}\left[\varepsilon_{\mathrm{kj}}\right]\right)$ is small, and the correlation of such bilateral rates $\left(\operatorname{Corr}\left[\varepsilon_{\mathrm{kj}}, \varepsilon_{\mathrm{kf}}\right]\right)$ is low. By imposing some restrictions on the distribution of the shocks one can identify more specific results. These results will hold under a generic distribution assumption, unless some very special cases of correlation occur. Assume 
an identical variance $\left(\mathbf{u}^{2}\right)$ for the bilateral exchange rates and a zero correlation across such rates. Then, the variability of sales of a representative firm in country $k$ is:

$$
\operatorname{Var}\left[\chi_{k}\right]=\sigma^{2} u^{2}\left[\left(\sum_{j=1}^{N} \eta_{j}^{2}\right)-\eta_{k}^{2}\right]
$$

Implication 1. Under flexible exchange rates, variability of sales is lower for firms in the location with the largest world share of manufacturing.

In order to focus on agglomeration, we want to know the effect of an increase in the size of one country $\left(d \eta_{k}\right)^{13}$ on the variability of firms' sales in that country and, therefore, on the incentive to locate there:

$$
\frac{d\left[\operatorname{Var}\left[\chi_{k}\right]\right]}{d \eta_{k}}<0
$$

Implication 2. Under flexible exchange rates, an increase in the market size of one country reduces the variability of sales of firms located there, and increases the incentive for all firms to locate in that country.

Consider now the case in which a group of ' $h$ ' countries (without loss of generality one can choose the first ' $h$ ' countries) decides to create a monetary union. The variability of sales for firms in different countries will be affected differently depending on whether the countries participate in the union or not. For countries external to the monetary union, the variability of firms' sales becomes larger than in the case where all countries have a flexible exchange rate:

$$
\operatorname{Var}\left[\chi_{k, \text { outside }}\right]=\sigma^{2} u^{2}\left[\left(\sum_{j=1}^{h} \eta_{j}\right)^{2}+\left(\sum_{j=h+1}^{N} \eta_{j}^{2}\right)-\eta_{k}^{2}\right]>\operatorname{Var}\left[\chi_{k}\right]
$$

while for members of the monetary union the opposite result holds:

\footnotetext{
${ }^{13}$ Note that $\eta_{k}$ represents both market and employment share of country $k$, but the agglomeration effect deriving from the market share is more important than the one from the employment size.
} 


$$
\operatorname{Var}\left[\chi_{k, \text { inside }}\right]=\sigma^{2} u^{2}\left[\sum_{j=h+1}^{N} \eta_{j}^{2}\right]<\operatorname{Var}\left[\chi_{k}\right]
$$

\section{Implication 3. When a group of countries create a monetary union, firms of member countries will enjoy more stable sales, whereas firms located in countries external to the union will face a larger variability of sales. One could therefore expect that EMU would give a negative externality to firms located in outside countries.}

\section{Mobility AND AgGlomeration}

Section III identifies the agglomeration incentive (Implication 1) and a reinforcing component (Implication 2), for a given country structure. This Section speculates on the implications of mobility of firms and labor for long-run agglomeration equilibria. One could endogenize the mobility choices (which would prevent the obtainment of closed form solutions) ${ }^{14}$ and simulate the model in the tradition of the economic geography literature; however, there would be no value added in terms of intuition, while the mathematical and computational burden would simply make the presentation obscure.

\section{A. Case 1: Mobility of Firms, No Labor Mobility}

As already described in the introduction, firms dislike variability of sales for a number of reasons. Hence, variability of the exchange rate in the presence of price rigidities induces firms to prefer the country with the lowest variability of sales, which is the country with the largest market share. ${ }^{15}$ Movement of firms to such a country has two effects: (1) it increases the incentive to locate in said country, as shown in Implication 2, because the market share of this country increases; (2) it reduces the same incentive as firms compete for workers and offer higher wages (hence higher costs of production). Identical expected profits for all firms all over the world imply that in equilibrium each firm in larger (smaller) countries is expected to produce a smaller (larger) output and to pay a higher (lower) wage. Hence, in the presence of mobility of firms, but not of labor, exchange rate variability induces a larger (but finite) concentration of firms in large markets.

\footnotetext{
${ }^{14}$ For any employment allocation, the wage will be determined by the number of firms (demand for labor) compatible with zero expected profits in all markets. Such expected profits would depend on the price, and hence on the wage, in a highly nonlinear fashion, as the price enters the demand and the variability of sales.

${ }^{15}$ Unless special correlation effects are at work.
} 


\section{B. Case 2: Labor Mobility, No Mobility of Firms}

Workers are indifferent to any location if they only care about the (linear approximation of the) expected real wage. If workers dislike variability of employment, they will prefer to go to the large region where variability of overall employment is lower (or equivalently, they would be willing to accept a lower wage in the large region).

\section{Case 3: Mobility of Firms and Labor}

In this case, there may be a circular chain of agglomeration effects (very similar to the forward and backward linkages) where firms tend to go to the larger market in order to enjoy a lower variability of sales, and workers want to go to the same market in order to enjoy a lower variability of employment. Abstracting from dispersion forces (see next paragraph), whether agglomeration will be full or not may depend on how strong is the incentive for workers. In fact, if workers are very mobile, it is likely that an increase in agglomeration of firms in the large location, by lowering variability of employment, will attract enough workers without having to raise wages (hence costs and prices). Therefore, more firms will follow (see case 1). If workers tend not to move, when firms attempt to relocate to the larger market, the firms will have to compete for workers, which raises the wage in that location and reduces the incentive for firms to move there.

\section{Dispersion Forces}

Dispersion forces would arise from the presence of trade costs and other factors such as: a location-specific constant returns to scale sector (Krugman, 1991), a location-specific factor of production for manufacturing (Puga 1997), public expenditure on local goods (Trionfetti, 1997), or other forms of congestion costs (Alonso Villar, 1996; Ricci, 1997c). These forces would dampen but would not reverse the described agglomeration effects due to exchange rate variability, and would usually prevent complete agglomeration (full concentration of firms in one location).

\section{E. Implication 4}

Implication 4. Exchange rate variability in the presence of price rigidities generates an agglomeration force which increases the concentration of firms in large markets.

It is worth noting that endogenizing the cost from variability of sales would strengthen agglomeration. One could adopt a quadratic input function (see, for example, Ricci 1997a), instead of the linear one usually assumed in new trade and location theory. In this case, the optimal price would be linear in expected sales, and variability of sales would enter the profit 
function directly, given that prices and wages are set in advance. Such production function would foster agglomeration because competition would induce firms to locate in large markets until expected sales in each location were such that expected profits were equalized across locations. In fact, Section III shows that, ceteris paribus, firms in the location with the lowest variability of sales enjoy higher expected profits; hence an equilibrium location can be reached only for a level of expected sales that is lower in larger regions. But, because of the quadratic input function, this would then imply lower optimal prices in such regions and a higher demand for local varieties than for varieties produced in smaller regions. Such higher demand for local varieties would in turn be reflected in even higher profits of local firms. Hence, more firms would be attracted to large markets, inducing even lower variability of sales, lower local prices, higher demand for local varieties, and so on. This circular chain reinforces agglomeration.

\section{EMPIRICAL EVIDENCE}

This section presents empirical evidence that is consistent with the predictions of the stylized model of this paper, i.e., that exchange rate variability induces agglomeration of economic activity. Gathering the evidence was not an easy task as there is no econometric study that can be considered a benchmark for the evidence of agglomeration, on which to control for the effect of exchange rate variability. The analysis begins with the variability of industrial production before and after the collapse of Bretton Woods in some OECD countries, and then examines the effect of exchange rate variability on the net flow of FDI.

\section{A. Variability of Industrial Production and Exchange Rate Regime ${ }^{16}$}

This Section investigates the variability of industrial production before and after the collapse of Bretton Woods (1973) in some OECD countries, and provides empirical evidence which is consistent with the theoretical Implications 1 and 2 of Section III: "Under flexible exchange rates, variability of sales is lower for firms in the location with the largest world share of manufacturing," and ". . a an increase in the market size of one country reduces the variability of sales of firms located there, and increases the incentive to locate in that country." It has been shown that the variability of industrial production is smaller in large countries (Head, 1995; and Lumsdaine and Prasad, 1997), probably due to the law of large numbers, a diversification effect, and a factor market pooling effect. The analysis developed in this Section shows that the negative effect of country size on variability of industrial production is stronger under flexible exchange rates.

\footnotetext{
${ }^{16}$ I owe to discussions with Eswar Prasad the idea of looking at the relation between variability of industrial production and country size in order to investigate the effect of the exchange rate regime on the aforementioned variability.
} 
Seasonally-adjusted monthly data on industrial production of 18 OECD countries ${ }^{17}$ from 1960.01 to 1993.12 are collected from the IFS data set. The sample is then divided in two periods: the first period spans from 1960.01 until 1973.06, and is named Bretton Woods (before 1960 the data set becomes too small). The second period contains the rest of the sample (1973.07-1993.12) and is named Post-Bretton Woods. For each country and for each of the two periods, the standard deviations of the monthly growth rates (IpBW, and IpPostBW) are calculated.

Two measures of relative country size are adopted. The first measure is the PPPadjusted GDP taken from the World Economic Outlook (WEO) data set of the IMF. The second measure is calculated using the Penn World Tables (PWT), by multiplying population and per capita GDP relative to United States (U.S. $=100$ ) in 1985 international prices. ${ }^{18}$ The regression results reported in Table 1 employ relative country size based on 1973 data (y73 for WEO and Py73 for PWT). Results based on many other years of both data sets were almost identical both quantitatively and qualitatively. Table 1a (at the end of the paper) lists the four variables mentioned.

In order to interpret the coefficient and reduce the interference of heteroscedasticity (highly likely in this cross-section analysis and difficult to detect properly given the small sample), all variables are expressed in logarithms. Hence, logs of standard deviation of the monthly growth rate of industrial production are regressed on the log of country size, for each of the two subperiods.

The results are reported in Table 1 . An increase in the country size by 100 percent reduces the standard deviation of industrial production by 18 percent in the Bretton Woods period and by 27 percent in the post-Bretton Woods period. Given the size of the standard errors (both OLS and heteroscedasticity-corrected standard errors, the correction being achieved with the White method) the coefficients can be considered significantly different. The fit is much better in the post-Bretton Woods period. In all regressions the null hypothesis of homoscedasticity cannot be rejected; the heteroscedasticity-corrected standard errors are reported for completeness, since it could be argued that the small sample does not allow rejection of the null hypothesis of homoscedasticity. As mentioned, the results are very similar for relative country size taken for years other than 1973.

\footnotetext{
${ }^{17}$ Australia, Austria, Belgium, Canada, Finland, France, Greece, Germany, Ireland, Italy, Japan, Luxemburg, Netherlands, Norway, Portugal, Spain, United Kingdom, United States.

${ }^{18}$ As all observations are in U.S. dollars, the difference between real and nominal GDP is a constant in the cross section regression.
} 
Table 1. Variability of Industrial Production Before and After the Collapse of Bretton Woods.

\begin{tabular}{|c|c|c|c|c|c|}
\hline & const & Ly73 & LPy 73 & $\mathrm{n}$ & $\mathrm{R} 2$ \\
\hline LipBW & $\begin{array}{c}-3.836 \\
(0.320) \\
{[0.320]} \\
\end{array}$ & $\begin{array}{l}-0.181 \\
(0.072) \\
{[0.075]}\end{array}$ & & 18 & 0.28 \\
\hline LIpBW & $\begin{array}{c}-2.017 \\
(0.999) \\
{[1.063]} \\
\end{array}$ & & $\begin{array}{l}-0.186 \\
(0.072) \\
{[0.077]}\end{array}$ & 18 & 0.29 \\
\hline LipPostBW & $\begin{array}{c}-3.371 \\
(0.199) \\
{[0.189]} \\
\end{array}$ & $\begin{array}{l}-0.269 \\
(0.045) \\
{[0.040]}\end{array}$ & & 18 & 0.69 \\
\hline LIpPostBW & $\begin{array}{l}-0.728 \\
(0.615) \\
{[0.585]}\end{array}$ & & $\begin{array}{l}-0.272 \\
(0.044) \\
{[0.041]}\end{array}$ & 18 & 0.70 \\
\hline
\end{tabular}

Standard errors in brackets

Heteroscedasticity-corrected (White method) standard errors in square brackets

y73 = relative country size from WEO database

Py73 = relative country size from PWT database

$\mathrm{IpBW}=$ standard deviation of the monthly growth rate of industrial production 1960.011973.06 (IFS)

IpPostBW = standard deviation of the monthly growth rate of industrial production 1973.07-1993.12 (IFS)

\section{B. Exchange Rate Variability and FDI}

This section looks for empirical evidence of agglomeration of effects of exchange rate variability by testing Implication 4 (Section IV): "Exchange rate variability in the presence of price rigidities generates an agglomeration force, which increases the concentration of firms in large markets." This is done by investigating the effect of exchange rate variability on the net flow of FDI. Because FDI is directly affected by firms' choices of location across countries, the net flow could inform us of the relative location choices made by firms. ${ }^{19}$

\footnotetext{
${ }^{19}$ The shortcoming of FDI is that its crude definition does not allow a clear differentiation between investment and portfolio decisions. FDI is classified as foreign ownership of more than 10 percent of ordinary shares or voting power.
} 
Several authors have argued that exchange rate variability induces firms to increase FDI. ${ }^{20}$ The basic theoretical argument is the following: if risk-averse firms commit to domestic and foreign output capacity before the realization of exchange rate shocks, a higher exchange rate variability would induce firms to increase their foreign capacity in order to reduce foreign currency exposure. ${ }^{21}$ Goldberg and Kolstad (1994) find evidence that exchange rate variability promotes gross flows of FDI, by looking at the bilateral nominal exchange rate and the bilateral FDI flows between the United States and three countries: Canada, Japan, and United Kingdom.

These studies concern gross FDI flows and tend to suggest that when exchange rate variability between two countries increases, all firms in both countries will increase FDI. However, we are left with the question of which country might be the net recipient. The argument developed in this paper is related more to net flows of FDI and suggests that large countries should receive relatively more net FDI when exchange rate variability increases.

\section{Data and Implementation}

In order to test whether large countries should receive relatively more net FDI when exchange rate variability increases, the previous sample of countries is divided into two groups: small and large. For each group, a panel data analysis of net FDI flows (normalized by GDP) is performed as a function of the variability of the nominal effective exchange rate and of the growth in real labor cost. ${ }^{22}$

The prior is that the variability of the effective exchange rate should have a negative effect on the net flow of inward FDI for small countries and a positive effect for large countries, indicating an agglomeration effect of exchange rate variability.

The previous Sections described a simple theoretical framework tailored to the analysis of the role of exchange rate variability in the presence of market rigidities. Obviously other factors not captured by the model affect location choices in general, and FDI in particular. In the empirical work, growth in real labor costs is introduced, which should have a

\footnotetext{
${ }^{20}$ See Cushman (1988), Goldberg and Kolstad (1994), Broll and Zilcha (1992), Broll, Wahl, and Zilcha (1996).

${ }^{21}$ Other key assumptions are: incomplete pass through and repatriation of profits.

${ }^{22}$ Considering flows of FDI between each country and the rest of the world, the effective exchange rate is the relevant variable through which to analyze the effect of exchange rate variability, as it is a trade-weighted average of the bilateral exchange rates. As the intuition derived from the theoretical framework is based on nominal exchange rate variability in the presence of price rigidities, the nominal exchange rate is adopted.
} 
negative effect on the net flow of inward FDI for all countries, as it may be expected to reduce the incentive to locate there. At the end of this section, the relevance of other factors for the results on exchange rate variability will be discussed.

The large country group includes Austria, France, Germany, Italy, Japan, Netherlands, United Kingdom, and United States. Austria and Netherlands are also added to this group, because their exchange rate were practically fixed with respect to the German mark over the sample period.

The small country group includes Australia, Belgium, Canada, Finland, Greece, Ireland, Norway, Portugal, and Spain. ${ }^{23}$

The variables used are the following:

FDIG = net inward FDI flow as a share of GDP (endogenous variable).

$\mathrm{E} 1=1$ year standard deviation of the monthly growth rate of the nominal effective exchange rate.

E3 $=3$ years standard deviation of the monthly growth rate of the nominal effective exchange rate.

$\mathrm{RLC1}=1$ year growth rate of the real labor cost.

$\mathrm{RLC} 2=1$ years growth rate of the real labor cost.

FDI is in millions of U.S.dollars from IFS. GDP is in millions of U.S.dollars from WEO (PPP-adjusted, 1992 base). Effective Exchange Rate and Real Labor Cost are from the OECD data set. The last variable is total labor cost of the private sector (wage bill plus contributions) per employee divided by GDP deflator.

For each of the two panels (large and small countries) an error correction formulation (with two lags) is implemented, in order to individuate the long-run relationship among variables. To eliminate the correlation of the residuals across countries, the method of estimation adopted is the generalized least squares.

${ }^{23}$ Because of the data availability Luxembourg has been dropped out of the sample. 
Table 2. FDI and Exchange Rate Variability: Small Country Panel, 1975-93

\begin{tabular}{|c|c|c|c|c|c|c|c|c|}
\hline \multicolumn{9}{|c|}{ Endogenous Variable: DFDIG } \\
\hline & \multicolumn{2}{|c|}{$\mathrm{E} 1, \mathrm{RLC} 1$} & \multicolumn{2}{|c|}{ E3, RLC1 } & \multicolumn{2}{|c|}{$\mathrm{E} 1, \mathrm{RLC} 2$} & \multicolumn{2}{|c|}{ E3, RLC2 } \\
\hline & coeff & $t$ & coeff & $t$ & coeff & $t$ & coeff & $t$ \\
\hline FDIG(-1) & $-0.51 * *$ & -8.10 & $-0.52 * *$ & -8.56 & $-0.54 * *$ & -8.69 & $-0.55^{* *}$ & -10 \\
\hline $\mathrm{E} @(-1)$ & $-493 * *$ & -6.40 & $-433 * *$ & -5.94 & $-586^{* *}$ & -6.9 & $-490 * *$ & -7.56 \\
\hline $\operatorname{RLC\# (-1)}$ & 43 & 1.38 & -12 & -0.45 & 20 & 1.44 & 15 & 1.10 \\
\hline \multicolumn{9}{|l|}{ DFDIG(-1) } \\
\hline \multicolumn{9}{|l|}{ DE@ } \\
\hline DE@(-1) & $139 * *$ & 2.64 & & & $265 * *$ & 3.35 & & \\
\hline DE@(-2) & & & & & $102^{*}$ & 2.08 & & \\
\hline DRLC\# & $-59 * *$ & -3.19 & $-57 * *$ & -2.99 & $-42 * *$ & -2.78 & $-43^{* *}$ & -2.90 \\
\hline DRLC\#(-1) & $-58 * *$ & -2.61 & & & & & & \\
\hline DRLC\#(-2) & $-45 * *$ & -2.72 & & & $-36 * *$ & -3.03 & $-38 * *$ & -3.60 \\
\hline
\end{tabular}

$\mathrm{D}$ before variable denotes change.

* and ** represent significance at the 5 percent and 1 percent level, respectively.

(a)=1,3 and $\#=1,2$ (see text for definitions of E1, E3, RLC1, RLC2) 
Table 3. FDI and Exchange Rate Variability: Large Country Panel, 1975-93

\begin{tabular}{|c|c|c|c|c|c|c|c|c|}
\hline \multicolumn{9}{|c|}{ Endogenous Variable: DFDIG } \\
\hline & \multicolumn{2}{|c|}{$\mathrm{E} 1, \mathrm{RLC} 1$} & \multicolumn{2}{|c|}{$\mathrm{E} 3, \mathrm{RLC} 1$} & \multicolumn{2}{|c|}{$\mathrm{E} 1, \mathrm{RLC} 2$} & \multicolumn{2}{|c|}{$\mathrm{E} 3, \mathrm{RLC} 2$} \\
\hline & coeff & $t$ & coeff & $t$ & coeff & $t$ & coeff & $t$ \\
\hline IFDIG(-1) & $-0.55^{* *}$ & -7.12 & $-0.60 * *$ & -7.67 & $-0.57 * *$ & -6.93 & $-0.60 * *$ & -7.38 \\
\hline $\mathrm{E} @(-1)$ & $406 * *$ & 2.82 & $725^{* *}$ & 3.42 & $405^{* *}$ & 2.79 & $843^{* *}$ & 3.81 \\
\hline RLC\#(-1) & $-59 * *$ & -3.74 & $-60 * *$ & -3.34 & $-26^{*}$ & -2.08 & $-51^{* *}$ & -2.96 \\
\hline \multicolumn{9}{|l|}{ DFDIG(-1) } \\
\hline DE@ & $143 * *$ & 2.71 & $541^{* *}$ & 3.13 & $149 * *$ & 2.75 & $589^{* *}$ & 3.28 \\
\hline DE@(-1) & $-232^{*}$ & -2.36 & $-616^{* *}$ & -4.05 & $-214^{*}$ & -2.14 & $-647 * *$ & -4.15 \\
\hline $\mathrm{DE} @ *(-2)$ & $117^{*}$ & 2.43 & & & $131^{* *}$ & 2.72 & & \\
\hline \multicolumn{9}{|l|}{ DRLC\# } \\
\hline \multicolumn{9}{|l|}{ DRLC\#(-1) } \\
\hline DRLC\#(-2) & & & & & & & $31^{*}$ & 2.04 \\
\hline $\begin{array}{l}\mathrm{D} \text { before var } \\
* \text { and ** rep } \\
@=1,3 \text { and } \hbar\end{array}$ & e deno & hange & - & $\square$ & avar & resp & ely. & \\
\hline
\end{tabular}

Tables 2 and 3 present the regressions for small and large countries respectively, once the insignificant variables in changes are dropped. For each country group four cases arise from the combination of the two kinds of exchange rate variability (one and three years standard deviation) and the two kinds of labor cost (one and two years growth rate). The main results can be summarized as follows:

1. for small countries, the variability of the effective exchange rate has a longrun negative effect on net inward FDI flows. There is no evidence of a long-run effect of the growth in real labor cost on net inward FDI. In the short-run, in all four cases the labor cost has a negative effect on net inward FDI, while in some cases variability of the exchange rate has a positive effect.

2. for large countries, the variability of the effective exchange rate has a longrun positive effect on net inward FDI flows, while growth in the real labor cost has a 
negative effect. Regarding the short run, there is contradictory evidence: considering the sum of the significative coefficients for each type of variable, there is almost no effect.

Another interesting finding is that the effect of exchange rate variability on FDI is also found without introducing labor costs in the regressions. Preliminary results of a work in progress by the author (1997d) show that the same conclusions regarding exchange rate variability hold in panel estimation of FDI with many more variables, such as labor tax, capital tax, growth in real income, and investment share of GDP.

Summing up the empirical findings in this section, the evidence shows that under flexible rates larger countries have a lower variability of industrial production, which is consistent with the theoretical implications of Section III, namely, that under flexible rates larger countries have a lower variability of sales and output. Further, exchange rate variability is found to have a negative effect on the net flow of inward FDI for small countries and a positive effect for large countries. Such an innovative result is consistent with the theoretical implication in Section IV, suggesting an agglomeration effect of exchange rate variability.

\section{Conclusions}

This paper identifies the agglomeration effect arising from exchange rate variability in the presence of short-run price rigidities. Exchange rate variability induces larger variability of sales for firms located in small markets than for those located in large markets. As firms dislike variability of sales, they prefer to locate in a large market, reinforcing the incentive to agglomerate. It is important to notice that such agglomeration effects arise purely from exchange rate variability and short-run price rigidities. These agglomeration effects are therefore independent of the usual forward and backward linkages emphasized by the economic geography literature.

The paper also presents empirical evidence consistent with the prediction of the model. First, the effect of exchange rate flexibility on variability of industrial output is investigated. Several studies have documented a negative effect arising from the size of a country on the variability of industrial production of that country. This paper shows that such effect is stronger in the post-Bretton Woods period: increasing the size of a country by 1 percent would reduce the variability of its industrial production by 0.18 percent during the period from 1960 to 1973 , and by 0.27 percent during the period from 1973 to 1993 . This stylized fact supports the theoretical implication that under flexible rates large countries have a lower variability of sales.

Second, the agglomeration effect of exchange rate variability is investigated by looking at the effect of the variability of nominal effective exchange rate on the net flow of inward FDI. Given the absence of established empirical analysis of location, FDI here is implicitly considered as a proxy for relative location choices. By dividing 17 OECD countries into two 
groups of small and large countries (where large includes the effective DM area) and by applying an error correction formulation to each panel, the analysis finds strong evidence of a negative long-run effect of exchange rate variability on the net flow of inward FDI for small countries, and a positive effect for large countries. ${ }^{24}$ This result suggests that when exchange rate variability increases, large countries become the relatively preferred target of FDI. Such a conclusion is perfectly consistent with the prediction of the model that exchange rate variability in the presence of market rigidities generates an incentive to locate in large markets.

Hence, this paper can provide a theoretical and empirical foundation to the speculation that U.S. firms usually have a smaller foreign currency exposure than foreign competitors, as they face a smaller exchange rate-induced demand shift thanks to the relative market size (Luehrman, 1990).

One important implication is that the creation of a currency area imposes a negative externality on firms outside the area, and could foster agglomeration in the currency area. Hence, countries joining EMU may be expected to attract firms at the expense of outside countries. Given the peripherality of countries that may not participate immediately in EMU, two-stage EMU may exacerbate the current uneven regional development. This agglomeration effect of the creation of a currency area is in contrast with the current perception of the effect of EMU on location choices. Martin (1995) suggests that when a currency union is formed, countries outside of the union have an incentive to engage in surprise inflation and devaluation in order to lower real wages and expand output at the expense of countries which are member of the union. This argument has led to the concern, usually expressed in political debates, that countries outside the (first group of countries participating in) EMU may then attract firms and employment at the expense of member countries. However, such an outcome requires that firms expect authorities to consistently manage to surprise wage setters, which would occur only if firms are smarter than wage setters. The reasoning presented in this paper, suggesting instead that the creation of the monetary union attracts firms in the union, is also based on price rigidities but is independent of policy actions and of the ability to consistently surprise agents.

While the model is very simplified and the empirical evidence very stylized, the results are intuitive, consistent, and suggestive, inducing stimulus for further research on the interaction between trade, location, and monetary issues both at the theoretical and the empirical levels.

\footnotetext{
${ }^{24}$ Preliminary results of a work in progress (Ricci, 1997d) show that the same results hold in a panel estimation of FDI with many more variables.
} 


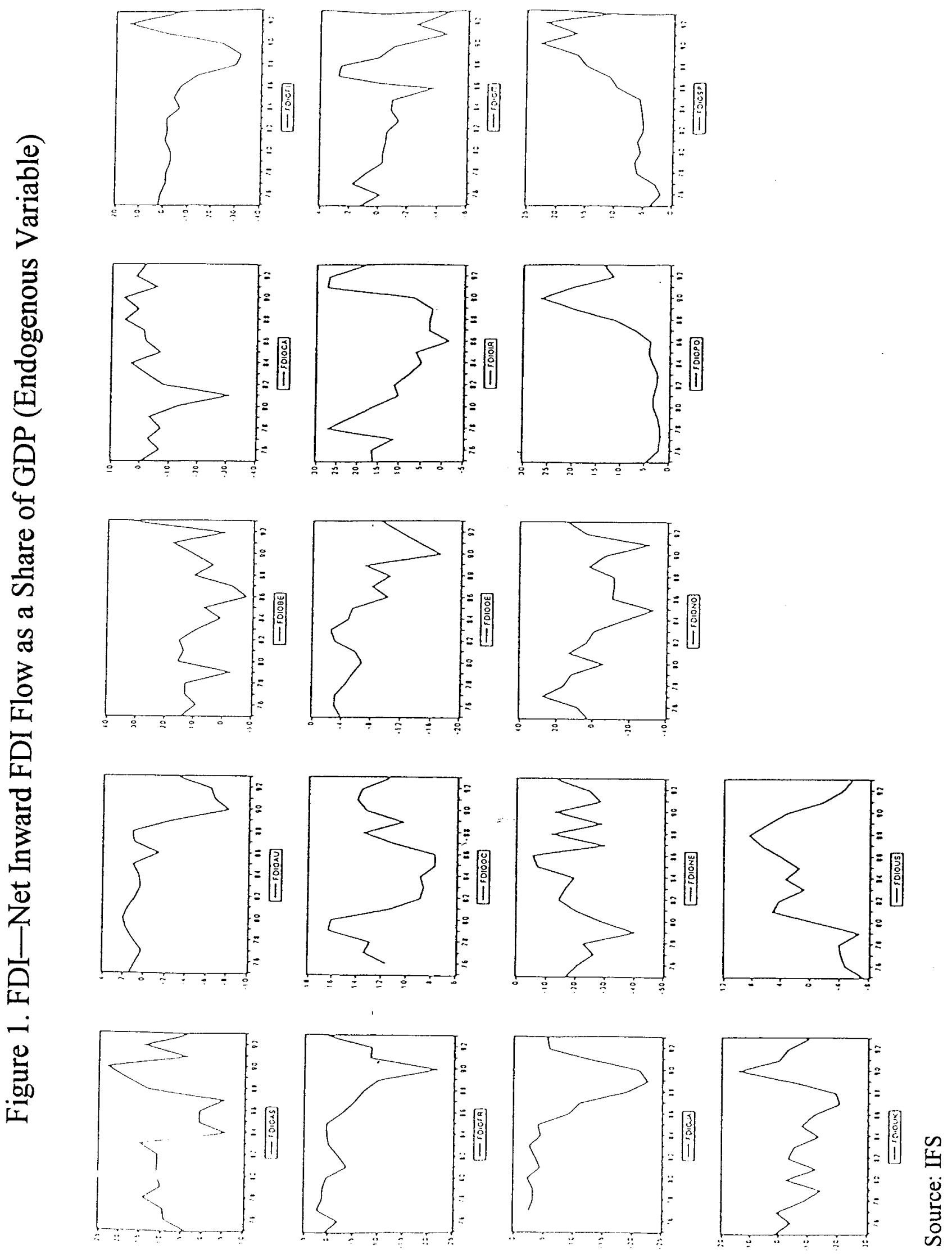



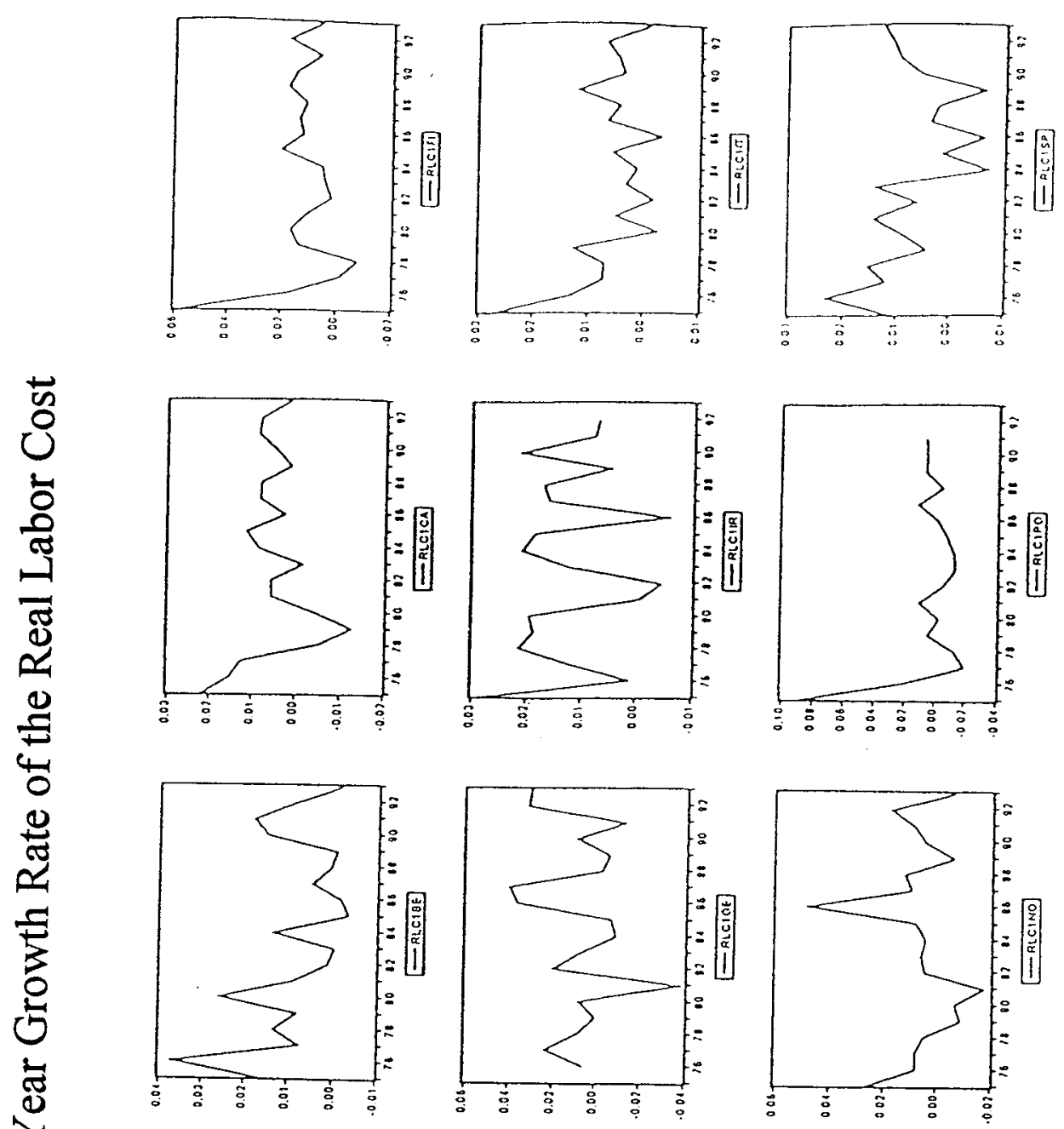

0ี
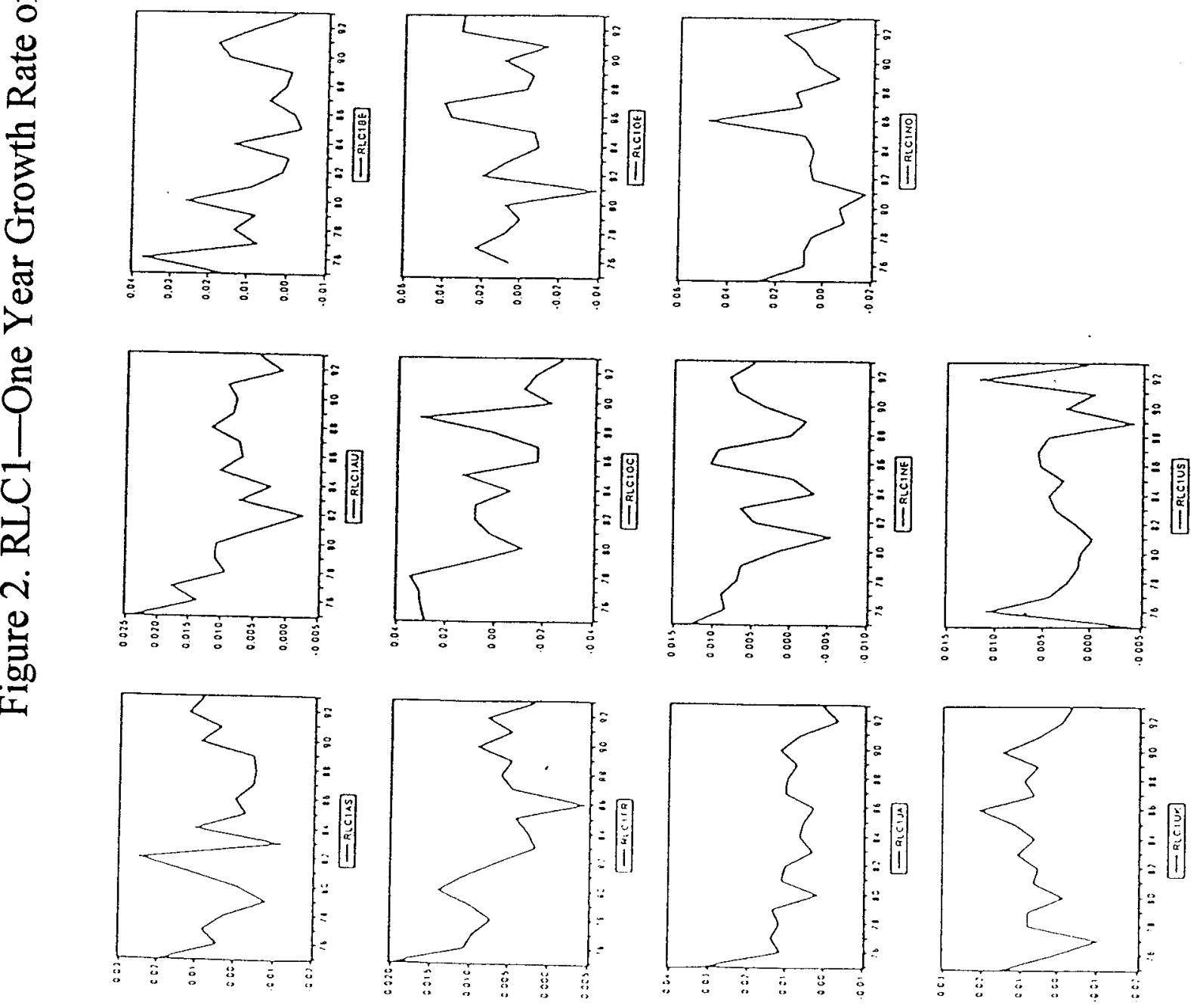

仓
1
0
0
0
0
0 

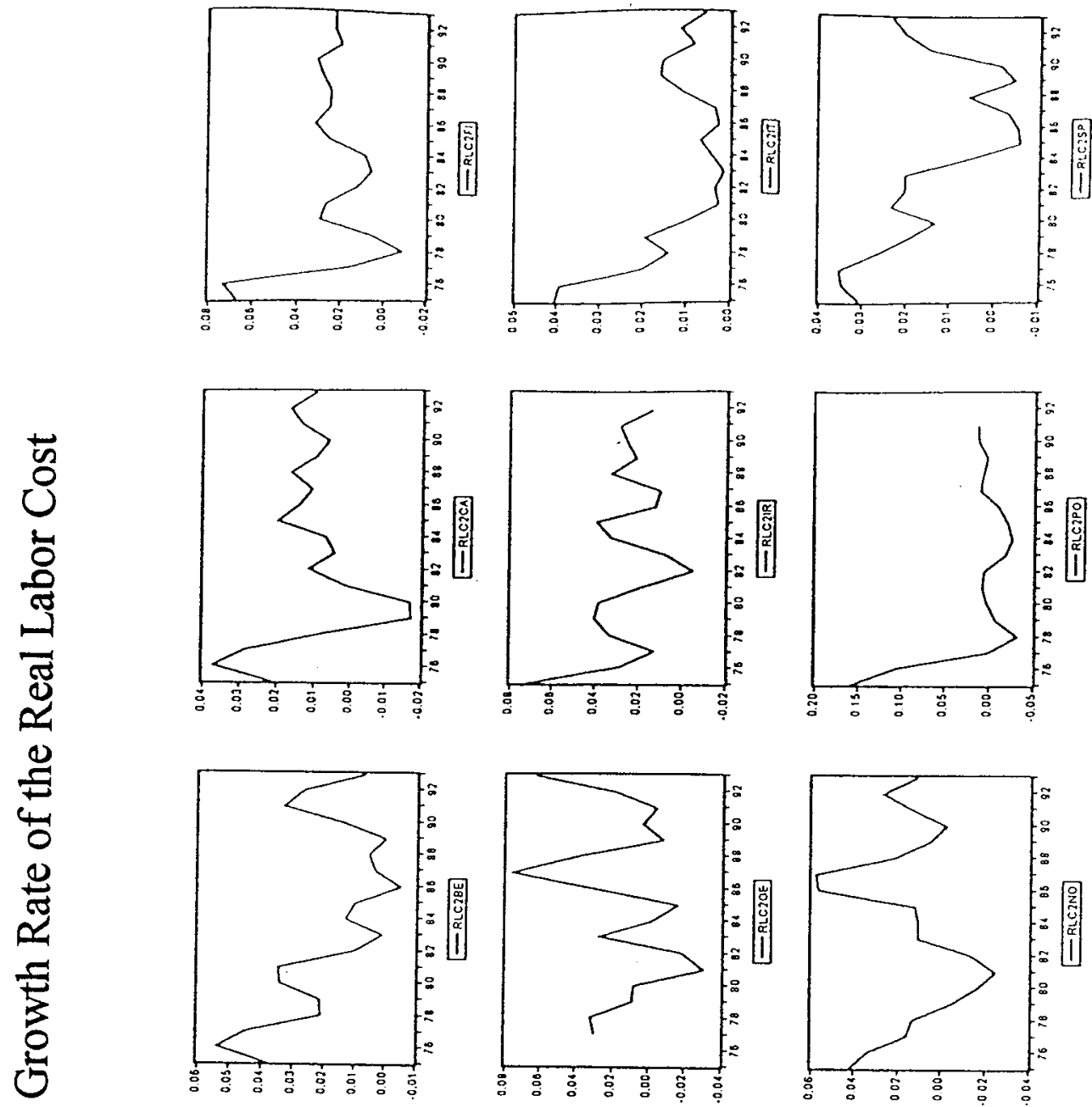

苛
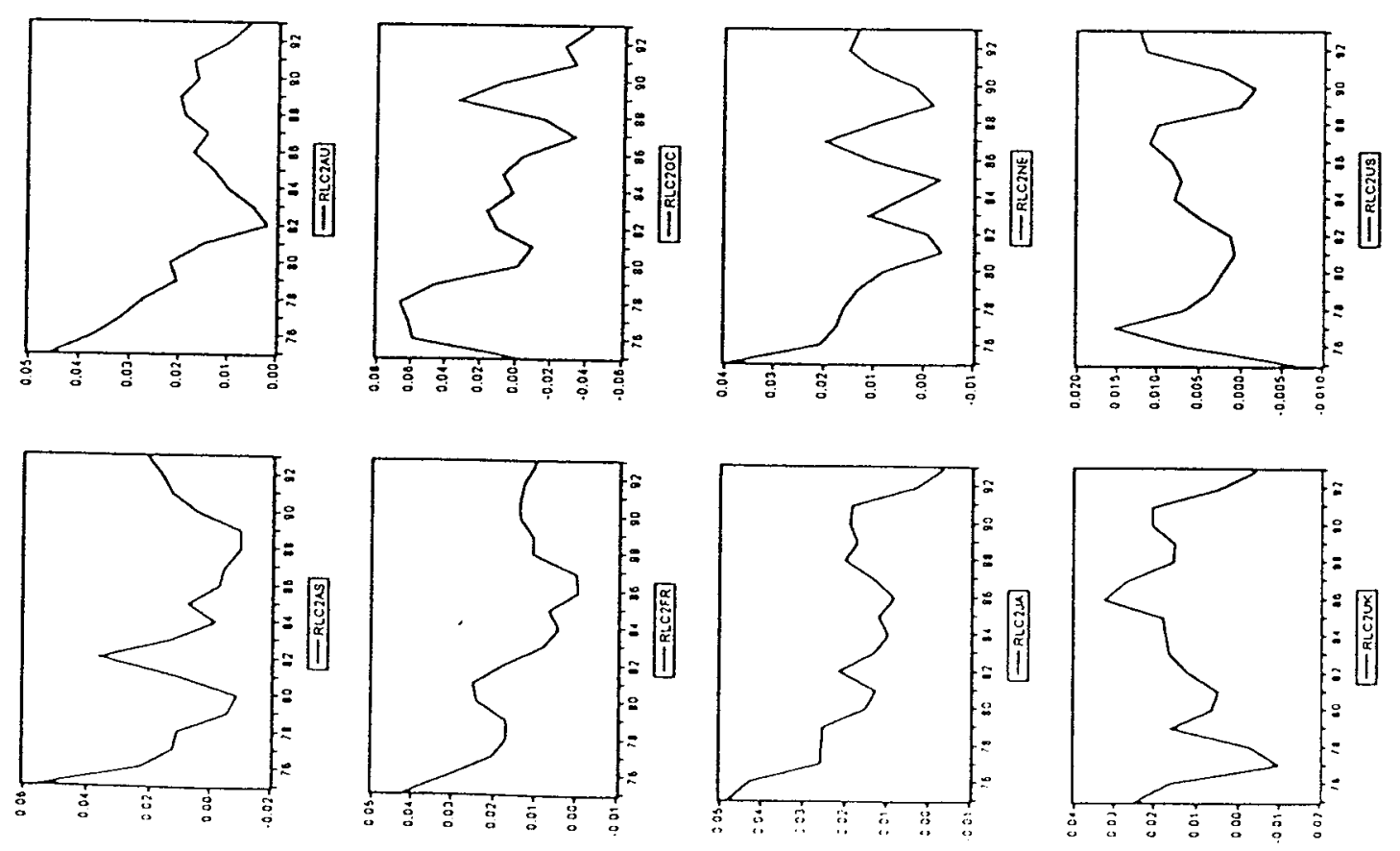

0
0
0
$\dot{8}$
0
0
0 


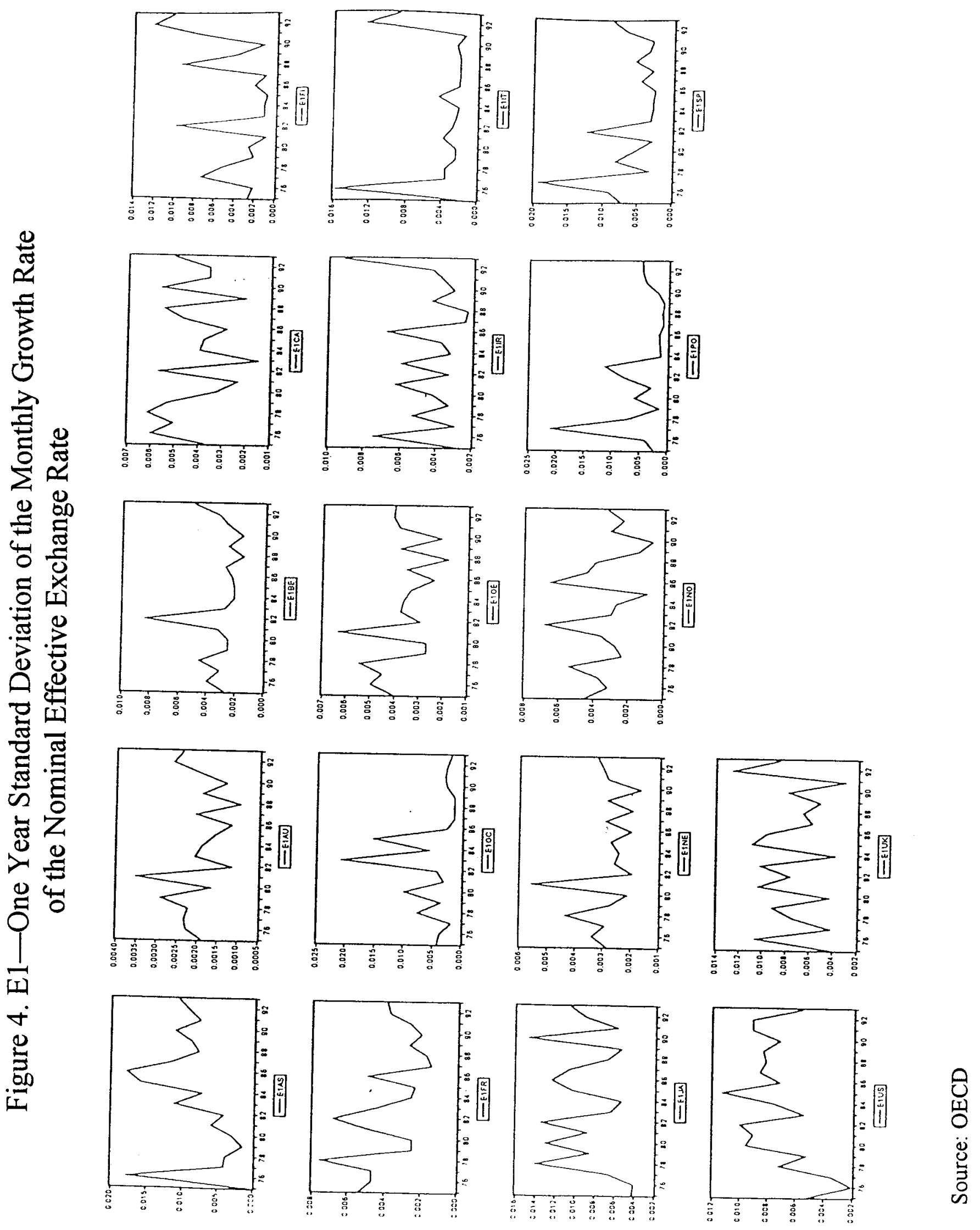



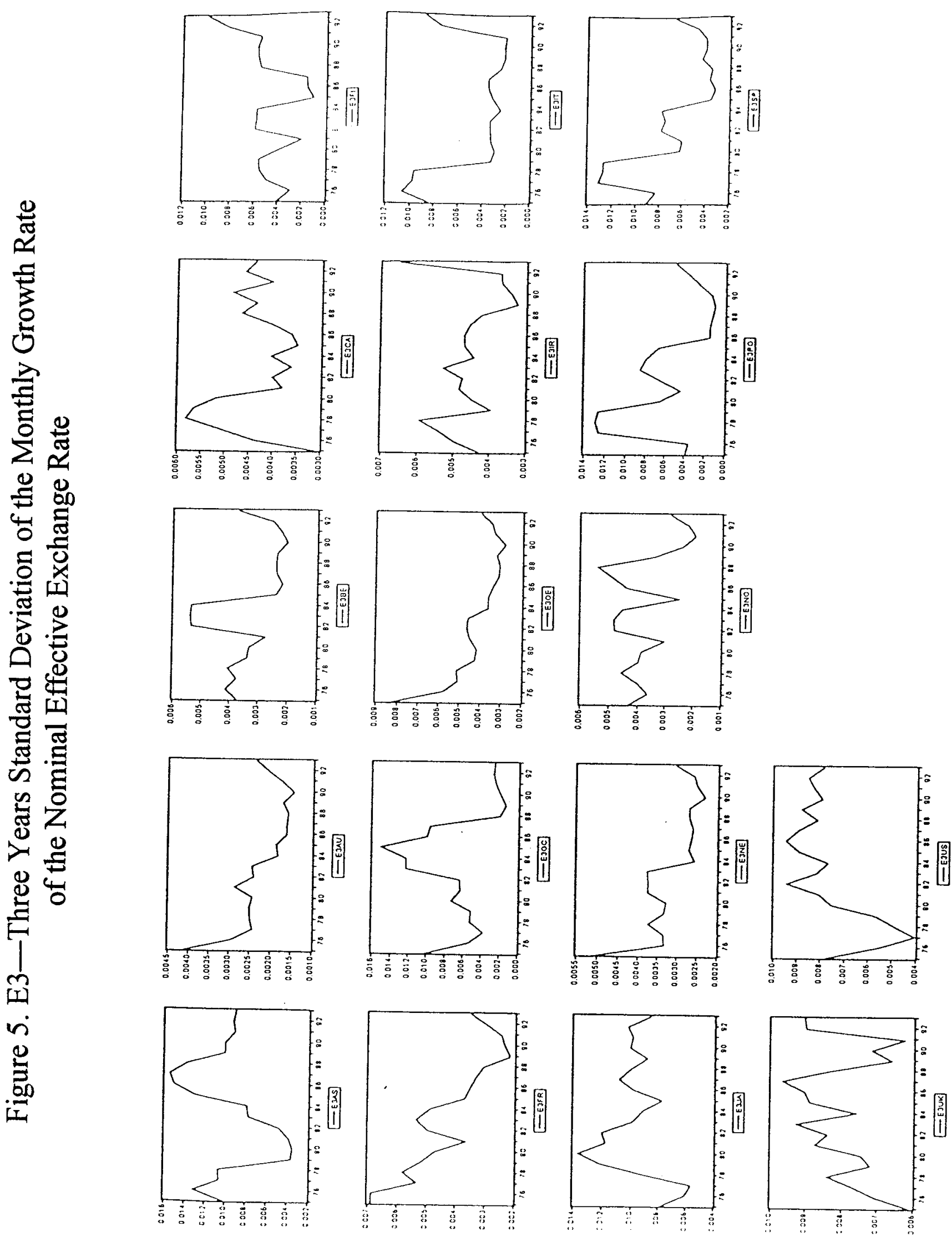

0
0
0
0
0
0
0
0 
Table 1a. STD of Industrial Production Growth Rate and Country Size

\begin{tabular}{|c|c|c|c|c|}
\hline Country & y73 & Py73 & $100 *$ IpBW & $100 *$ IpPostBW \\
\hline Australia & 60.08 & $1,082,422.0$ & 0.45 & 1.11 \\
\hline Austria & 31.40 & $453,935.3$ & 1.46 & 0.98 \\
\hline Belgium & 42.00 & $659,262.0$ & 1.85 & 1.60 \\
\hline Canada & 109.10 & $1,754,724.0$ & 0.45 & 0.61 \\
\hline Finland & 18.40 & $297,224.2$ & 1.50 & 1.15 \\
\hline France & 243.70 & $3,799,402.0$ & 1.87 & 0.68 \\
\hline Greece & 18.90 & $312,515.0$ & 1.21 & 1.65 \\
\hline Germany & 319.50 & $4,518,050.0$ & 0.87 & 0.82 \\
\hline Ireland & 7.30 & $122,920.0$ & 2.00 & 1.66 \\
\hline Italy & 212.00 & $3,104,382.0$ & 1.36 & 1.19 \\
\hline Japan & 420.40 & $6,592,819.0$ & 0.55 & 0.62 \\
\hline Luxemburg & 2.10 & $30,322.7$ & 1.00 & 2.18 \\
\hline Netherlands & 61.10 & $959,544.6$ & 0.64 & 1.22 \\
\hline Norway & 14.20 & $242,017.1$ & 1.42 & 2.13 \\
\hline Portugal & 20.60 & $269,349.6$ & 2.00 & 2.83 \\
\hline Spain & 108.70 & $1,670,880.0$ & 1.17 & 1.47 \\
\hline United Kingdom & 243.00 & $3,637,628.0$ & 0.69 & 0.70 \\
\hline United States & 1350.50 & $21,190,900.0$ & 0.35 & 0.38 \\
\hline \multicolumn{5}{|c|}{$\begin{array}{l}\text { y73 = relative country size from WEO database } \\
\text { Py73 = relative country size from PWT database } \\
\text { IpBW = standard deviation of the monthly growth rate of industrial production } \\
\quad 1960.01-1973.06 \text { (IFS) } \\
\text { IpPostBW = standard deviation of the monthly growth rate of industrial production } \\
\quad 1973.07-1993.12 \text { (IFS) }\end{array}$} \\
\hline
\end{tabular}

Note: The following figures represent the five variables used in Section V for each country 1975-93. See Section V.C for definitions, units, and source. 


\section{REFERENCES}

Alonso, Villar O., 1996, "Configuration of Cities: the Effects of Congestion Costs and Government," paper presented at the IInd meeting of the ESF-funded research group on "European Economic Performance" (London: LSE-CEP, June 28-30).

Blanchard, O.J., and N., Kiyotaki, 1987, "Monopolistic Competition and the Effects of Aggregate Demand," American Economic Review, Vol. 77.

Broll, U., J.E. Wahl, and I. Zilcha, 1995, "Indirect Hedging of Exchange Rate Risk," Journal of International Money and Finance, Vol. 14, No. 5.

Broll, U., and I. Zilcha, 1992, "Exchange Rate Uncertainty, Futures Markets and the Multinational Firm," European Economic Review, No.36

Cushman, D.O., 1988, "Exchange-Rate Uncertainty and Foreign Direct Investment in the United States," Weltwirtschaftliches Archiv, Vol. 124, No. 2.

Dixit, A., and J.E. Stiglitz, 1977, "Monopolistic Competition and Optimum Product Diversity," American Economic Review, Vol. 67.

EC Commission, 1990, "One Market, One Money: An Evaluation of the Potential Benefits and Costs of Forming an Economic and Monetary Union," European Economy, Vol. 44.

Eichengreen, Barry, 1990, "Is Europe an Optimum Currency Area?" NBER working papers, No. 3579

Elizondo, R.L., and P. Krugman, 1992, "Trade policies and Third World Metropolis" (mimeo; MIT).

Fatas, A., 1997, "EMU: Countries or Regions? Lessons from the EMS Experience," CEPR Discussion Paper No. 1558.

Frankel, J., and A. Rose, 1996, "The Endogeneity of the Optimum Currency Area Criteria," paper presented at the ESEM 1996, Istanbul.

Goldberg, L.S., and C.D. Kolstad, 1994, "Foreign Direct Investment, Exchange Rate Variability and Demand Uncertainty," NBER No. 4815.

Head, A., 1995, "Country Size, Aggregate Fluctuations, and International Risk Sharing," Canadian Journal of Economics, Vol.28, No.4b. 
Helpman, E., 1996, "The Size of Regions," presented at the CEPR-CUSO conference on 'Trade, Location, and Technology' (Switzerland: Champery, February 16-21).

Helpman, E., and P. Krugman, 1985, Market Structure and Foreign Trade (Cambridge; Massachusetts: MIT Press).

Krugman, P., 1993, "Lessons of Massachusetts for EMU," in Adjustment and Growth in the European Monetary Union, ed. by F. Torres and F. Giavazzi (Cambridge: Cambridge University Press).

$\longrightarrow$, 1991, Geography and Trade (Cambridge; Massachusetts: MIT Press).

— 1990, "Policy Problems for a Monetary Union," in The European Monetary System in the 1990's, ed. by P. De Grauwe and Papademos (London, England: Longman).

Krugman, P., and A.J. Venables, 1996, "Integration, Specialization, and Adjustment," European Economic Review.

Luehrman, T., 1990, “The Exchange Rate Exposure of a Global Competitor," Journal of International Business Studies, Vol. 21, No. 2, pp. 225-42.

Lumsdaine, R., and Eswar Prasad, 1997, "Identifying the Common Component in International Economic Fluctuations," NBER Working Paper No. 5984.

Martin, P., and G.I.P. Ottaviano, 1996, "Growing Locations: Industry and R\&D Location in a Model of Endogenous Growth," presented and the CEPR-CUSO conference on 'Trade, Location, and Technology' (Switzerland: Champery, February 16-21).

Martin, P., and C.A. Rogers, 1995, "Industrial Location and Public Infrastructure," Journal of International Economics.

Martin, P., 1995, "Free Riding, Convergence and Two-speed Monetary Unification in Europe," European Economic Review, Vol. 39, pp.1345-64.

Puga, D., 1997, "The Rise and the Fall of Regional Inequalities," paper presented at the CEPR-NBER ISIT conference, Paris, May 22-25.

Ricci, Luca A., 1997a, "Exchange Rate Regimes and Location," IMF Working Paper No. 97/69 (Washington: International Monetary Fund).

— 1997b, "A Model of an Optimum Currency Area," IMF Working Paper No. 97/76 (Washington: International Monetary Fund). 
— 1997c, "Economic Geography and Comparative Advantage," paper presented at the CEPR-NBER ISIT conference, Paris, May 22-25.

—, 1997d, "Exchange Rate Variability and FDI," IMF, manuscript in progress.

Trionfetti, F., 1997 (forthcoming), "Public Expenditure and Economic Geography," Annales d'Economie et de Statistiques.

_ 1996, "Single Market and the Sustainability of Public Debt," presented at the Ist meeting of the ESF-funded Research Group on 'European Economic Performance,' Louvain-la-Neuve, April 26-28.

Venables, A.J., 1996, "Equilibrium Location of Vertically Linked Industries," International Economic Review. 